\title{
Plant-soil feedback is shut down when nutrients come to town
}

\author{
Dina in 't Zandt $(\mathbb{D} \cdot$ Annelien van den Brink • \\ Hans de Kroon • Eric J. W. Visser
}

Received: 24 January 2019/Accepted: 21 March 2019/Published online: 6 April 2019

(C) The Author(s) 2019

\begin{abstract}
Background and aims The concept of plant-soil feedback is increasingly used to explain plant community assembly processes. Soil nutrient availability can be expected to play a critical role on these processes. However, little is known about the effects of nutrient availability on feedback direction and strength.

Methods A plant-soil feedback experiment was performed with the grasses Anthoxanthum odoratum and Festuca rubra, and the forbs Leontodon hispidus and Plantago lanceolata, on soil with either low or high nutrient availability. Additionally, we tested if plantsoil feedback of the two forbs under these conditions changed by inoculation of the soil with spores of an arbuscular mycorrhizal fungus.

Results Increased nutrient availability neutralised plantsoil feedback based on shoot biomass independent of its negative or positive direction, whereas the effects on root biomass were either not altered or turned negative. Mycorrhizal fungi spore addition decreased negative feedback and increased positive feedback.
\end{abstract}

Responsible Editor: Luca Bragazza.

Electronic supplementary material The online version of this article (https://doi.org/10.1007/s11104-019-04050-9) contains supplementary material, which is available to authorized users.

D. in 't Zandt $(\bowtie) \cdot$ A. van den Brink $\cdot$ H. de Kroon •

E. J. W. Visser

Department of Experimental Plant Ecology, Institute for Water and Wetland Research, Radboud University, Heyendaalseweg 135, 6525 AJ Nijmegen, the Netherlands e-mail: d.intzandt@science.ru.nl
Conclusions Our results suggest that negative plant-soil feedback on low nutrient soil can be overcome with nutrient addition, and that positive soil biota associations on low nutrient soil may become superfluous with nutrient increase. We hypothesize that species-specific, microbial mediated plant community assembly processes occur in low rather than high nutrient environments.

Keywords Plant-soil feedback · Soil nutrients · Mycorrhizae $\cdot$ Soil biota $\cdot$ Species-specific $\cdot$ Plant community assembly $\cdot$ Anthoxanthum odoratum . Festuca rubra $\cdot$ Leontodon hispidus $\cdot$ Plantago lanceolata

\section{Introduction}

Plant species co-existence, succession and invasion processes are commonly linked to responses between the plant and its surrounding soil. This so called plant-soil feedback is defined as changes to soil properties induced by plants, which in turn affect these same or other individuals in the plant community positively or negatively (van der Putten et al. 2013). The term plant-soil feedback thus encases a large variety of soil property changes; however, it is particularly the microbial changes that are considered to play driving roles in plant community assembly (e.g., Van der Putten et al. 2013; Bever et al. 2015). Key in this theoretical framework is the accumulation of species-specific microbial communities in and around the plant's root system, which generate species-specific plant-soil feedback ranging 
from strongly negative to moderately positive (e.g., Klironomos 2002; Petermann et al. 2008; Cortois et al. 2016). Especially negative feedback is regarded as imperative to plant species community processes, because negative feedback is a form of negative frequency dependence implying that successful species limit their own growth when in high abundance (e.g., Bever et al. 1997, 2015). There has been considerable progress in understanding the processes that link plant-soil feedback to such natural plant community assembly processes. However, how the environment affects plant-soil feedback strength and direction has yet received relatively little attention (Ke and Miki 2015; Lekberg et al. 2018; Erktan et al. 2018).

Belowground communities are suggested to be predominantly structured by environmental conditions such as soil fertility (Ramirez et al. 2010; Tedersoo et al. 2014; Lekberg and Waller 2016; Laliberté et al. 2017). Increases in soil nutrient availability decreases soil microbial biomass (Treseder 2008; Mitchell et al. 2010; Ramirez et al. 2012, but see Manning et al. 2008), and shifts bacterial, fungal and archaeal soil community composition (e.g., Ramirez et al. 2010; Bates et al. 2011; Leff et al. 2015). These shifts in microbial community composition were consistent in grasslands across the globe (Leff et al. 2015), and, for nitrogen enrichment, also across biomes in general (Fierer et al. 2009; Ramirez et al. 2012). Such consistent changes are expected to interact with plant growth and hence to affect plant-soil feedback driven community assembly processes (e.g., Ehrenfeld et al. 2005; Luo et al. 2017). However, the few studies testing nutrient availability yield mixed results (Manning et al. 2008; Petermann et al. 2008; Harrison and Bardgett 2010), introducing two contrasting theories on how nutrient addition affects plant-soil feedback strength and direction via microbial community composition shifts.

Plant-soil feedback is, on the one hand, thought to become increasingly negative with increasing nutrient availability, because nutrients are expected to stimulate antagonistic soil biota and suppress protagonists (Rúa and Umbanhowar 2015; Revillini et al. 2016; van der Putten et al. 2016; Lekberg et al. 2018). This complies with studies showing an increase in pathogen abundance in the soil with increasing nutrient availability (Paungfoo-Lonhienne et al. 2015; Wei et al. 2018; Veach et al. 2018). Moreover, this increase in soil pathogens was shown to result in increased negative plantsoil feedback of Panax notoginseng, Chinese ginseng, with high nitrogen addition to this production system (Wei et al. 2018). However, for more natural systems, this remains untested.

Soil protagonist studies mainly focus on widespread mutualistic interactions between plants and mycorrhizal fungi that provide a competitive advantage to the plant via nutrient uptake and protection against pathogens (Sikes 2010). Stimulation of the mycorrhizal fungi community resulted largely in positive plant-soil feedback effects (Anacker et al. 2014; García-Parisi and Omacini 2017). These interactions generally decrease with nutrient addition (e.g., Egerton-Warburton and Allen 2000; Corkidi et al. 2002; Leff et al. 2015) suggesting that suppression of mycorrhizal protagonists via soil nutrient increase, strengthens negative feedback. However, we are unaware of any studies that have tested this interaction effect between nutrients and protagonist soil biota on plant-soil feedback.

On the other hand, theory predicts plant-soil feedback to become less negative with increasing nutrient availability. This may result from decreased nutrient stress, increase in overall fitness and an elevated tolerance to soil-borne pathogens by the plants in high nutrient environments. Support for this opposing hypothesis can be found in experiments by Petermann et al. (2008), who showed a partial decrease in negative plantsoil feedback across 24 European grassland species with nutrient addition. This was tested by comparing plant growth between soils where the same plant species had grown on before (own conditioned soil) and soil where another species had grown on (foreign conditioned soil) with and without nutrient addition. However, the authors note that the observed partial decrease in negative plant-soil feedback with nutrient addition could result from either an interaction effect of nutrients and soil biota, or from reducing nutrient limitation on own soils conditioned by acquisitive species compared to foreign conditioned soils of more conservative species.

This overview shows that the literature on interactions between plant soil-feedback and soil nutrients is far from conclusive. Here, we tested this interaction and, moreover, assessed the role of common soil protagonists in plant-soil feedback relations. In particular, we performed a greenhouse plant-soil feedback experiment with two grasses, Anthoxanthum odoratum and Festuca rubra, and two forbs, Leontodon hispidus and Plantago lanceolata, on low and high nutrient soil. For the species that showed a fast response to mycorrhizal fungi spore 
addition in the seedling phase, Leontodon and Plantago, we stimulated mycorrhizal root colonisation by adding mycorrhizal spores to the seedlings in a full-factorial design with soil nutrient availability. We asked (i) whether nutrient addition changes plant-soil feedback direction and strength, and (ii) whether increased exposure to arbuscular mycorrhizal fungi affects plant-soil feedback and how this response interacts with the response to nutrient availability. Based on our results, we discuss the role of nutrients and mutualistic interactions in shaping plant-soil feedback and the implications of these factors on plant community assembly processes.

\section{Material and methods}

Experimental design

A plant-soil feedback pot experiment with a conditioning and a feedback phase was performed for two grasses, Anthoxanthum odoratum and Festuca rubra, and two forbs, Leontodon hispidus and Plantago lanceolata. In the feedback phase, each species was grown on soil that had been conditioned by the same species, and, as a control, on a mixture of all four conditioned soils. All species were also grown with low and high nutrient availability in a fullfactorial design with soil history $(n=6$; Fig. 1$)$. A pilot experiment showed that addition of spores of the generalist Rhizophagus irrigularis mycorrhizal fungus to seedlings (details see below) significantly increased mycorrhizal fungi colonisation in roots of Leontodon and Plantago, but not in roots of Anthoxanthum and Festuca (Fig. S1). Shoot biomass was not significantly affected, indicating that inoculation with mycorrhizal spores did not have immediate negative, parasitic effects on plant growth (data not shown). Only Leontodon and Plantago were, therefore, considered to show a sufficiently rapid response to mycorrhizal spore addition and, as a result, to potentially be affected in their plant-soil feedback by stimulation of mycorrhizal fungi colonisation. These two species were in the feedback phase also grown with and without addition of spores of the mycorrhizal fungus in a full-factorial design with nutrient status and soil history ( $n=6$; Fig. 1 ).

Conditioning phase

Seeds of the four species (De Bolderik, Wervershoof, the Netherlands) were surface sterilised by shaking in $1.35 \%$ commercial bleach (diluted $1: 1$ ) for $30 \mathrm{~min}$ at $140 \mathrm{rpm}$. After thorough rinsing with demi-water, seeds were incubated in sterile petri-dishes $(\varnothing 9 \mathrm{~cm})$ lined with wet filter paper. Growth room conditions for germination were $25^{\circ} \mathrm{C}$ during the $12 \mathrm{~h}$ light period (MASTER TL-D Reflex 18 W/840 lights, Phillips Lighting B.V., Eindhoven, the Netherlands) at, on average, $55 \mu \mathrm{mol}$

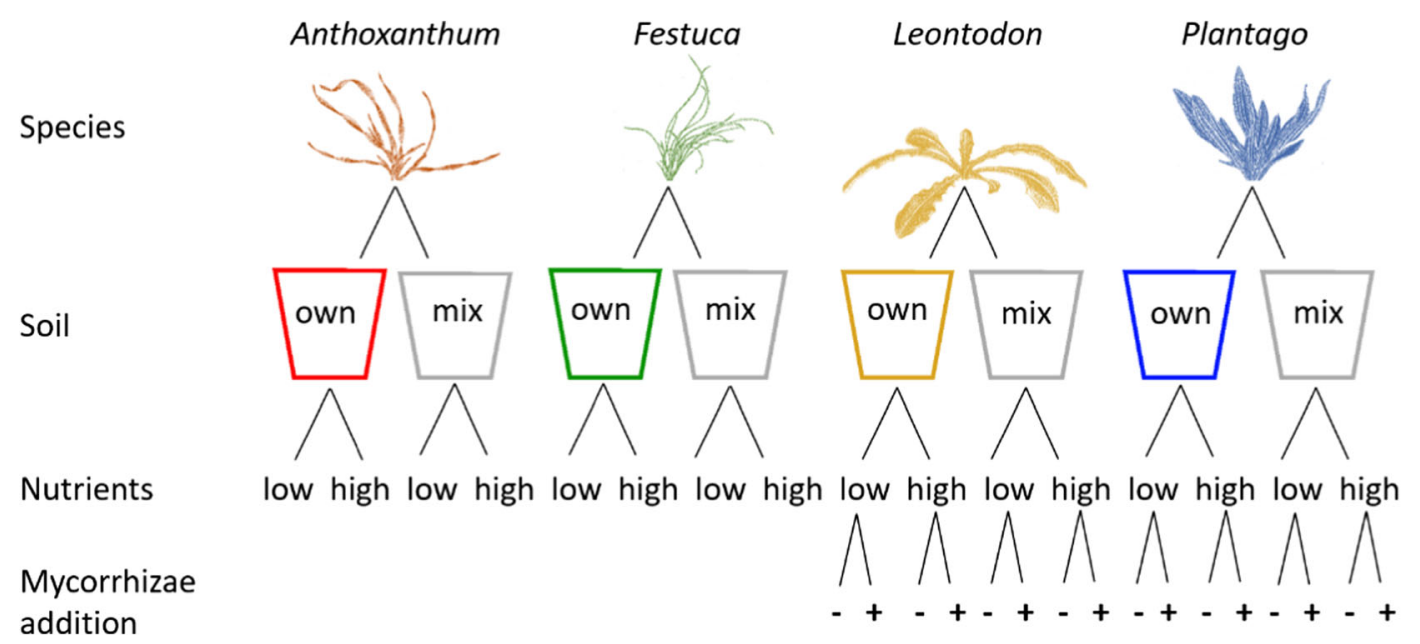

Fig. 1 Experimental setup of the feedback phase. Four species, Anthoxanthum odoratum, Festuca rubra, Leontodon hispidus and Plantago lanceolata, were grown on soil conditioned by the same species (own) and on a mixture of all four conditioned soils (mix). Both own and mix soil received no addition of nutrients (low) and

addition of a nutrient solution each week (high). Leontodon and Plantago were, in addition, planted without $(-)$ and with addition of spores of a mycorrhizal fungus (+). This was done in a fullfactorial design and resulted in 24 treatments $(n=6)$ 
PAR $\mathrm{m}^{-2} \mathrm{~s}^{-1}$ at petri dish level and $10^{\circ} \mathrm{C}$ during the $12 \mathrm{~h}$ dark period. Seedlings were carefully transferred to pots once their cotyledon(s) had emerged. Seed germination of the different species was timed to have the same transfer day.

Eight seedlings per species were transferred into disinfected ( $3 \mathrm{~d}$ in $1 \%$ MENNO clean, KaRo BV, Zwaagdrijk, the Netherlands), free draining $1.5 \mathrm{~L}$ pots (top diameter $13 \mathrm{~cm}$, bottom diameter $11.5 \mathrm{~cm}$, height $15 \mathrm{~cm})$ lined with root cloth at the bottom $(n=48)$. Pots were filled with a loamy soil (30\% sand, $60 \%$ loam, $10 \%$ clay; Schinnen, the Netherlands) sieved at $1 \mathrm{~cm}$ mesh and placed in dishes to prevent nutrient leaching. Seedlings were thinned to four evenly distributed individuals per pot within the first $10 \mathrm{~d}$ and grown for 8 weeks in the greenhouse between 20 and $24{ }^{\circ} \mathrm{C}$ during the $16 \mathrm{~h}$ light period (MASTER GreenPower Plus 1000 W EL/5X6CT lights, Phillips Lighting B.V., Eindhoven, the Netherlands) at minimally $250 \mu \mathrm{mol}$ PAR $\mathrm{m}^{-2} \mathrm{~s}^{-1}$ at pot level and $17-20{ }^{\circ} \mathrm{C}$ during the $8 \mathrm{~h}$ dark period. Pots were watered 3-5 times a week with deionised water. After 8 weeks, the shoot was cut off below the growing point and soil with roots was cut into clumps of 2-3 cm. All cut soil pots of each species were pooled and thoroughly mixed, and the mix of the four species-specific soils was made by pooling and thoroughly mixing half of the total amount of each conditioned soil $(w / w)$. For each conditioned soil, plant available nitrogen $(\mathrm{N})$ and potassium (K) (mg kg-1 dry soil) was determined by adding $50 \mathrm{~mL}$ of $0.2 \mathrm{M} \mathrm{NaCl}$ to $10 \mathrm{~g}$ of fresh soil, shaking for $2 \mathrm{~h}$ at $120 \mathrm{rpm}$ and filtering the soil out. $\mathrm{NO}_{3}{ }^{-}, \mathrm{NH}_{4}{ }^{+}$and $\mathrm{K}^{+}$concentrations were measured on an AutoAnalyzer 3 (Bran+Luebbe $\mathrm{GmbH}$, Norderstedt, Germany) $(n=3)$. Plant available phosphorous (P) (mg kg-1 dry soil) was determined according to Olsen et al. (1954) and measured on an ICP-OES iCAP 6000 (Thermo Fisher Scientific Inc., Waltham, MA, USA) $(n=3)$. Mainly $\mathrm{NO}_{3}{ }^{-}$levels between the own soil of the four species and the mix soil differed at the start of the feedback phase (Fig. S2). The amount of $\mathrm{NO}_{3}{ }^{-}$added over the whole growing period $\left(7480 \mu \mathrm{mol} \mathrm{kg}{ }^{-1}\right)$ in the high nutrient treatment was 4 to 7 fold larger than the difference in $\mathrm{NO}_{3}{ }^{-}$that occurred between own and mix soil treatments. Initial differences in nutrient concentrations in the conditioned soils were thus minor compared to nutrient addition treatments.
Feedback phase

From a second batch of seedlings that were germinated in the same way as for the conditioning phase, eight seedlings per species were transferred into the same size of pots as in the conditioning phase and thinned to four individuals per pot within the first $10 \mathrm{~d}$. Leontodon and Plantago seedlings with mycorrhizal fungi addition were planted in dents filled with a mixture of $2.9 \mathrm{~g}$ dry soil with $0.1 \mathrm{~g}$ Rhizophagus irrigularis spores in attapulgit powder (approximately 1000 spores per dent, 4000 per pot; strain DAOM197198; Symplanta GmbH \& Co. KG, Darmstadt, Germany). Pots were watered every 3-5 d with deionised water. Once a week, with exception of week six, high nutrient pots received $200 \mathrm{~mL}$ nutrient solution $\left(9350 \mu \mathrm{mol} \mathrm{L}{ }^{-1} \mathrm{NO}_{3}{ }^{-}\right.$, $1115 \mu \mathrm{mol} \mathrm{L}{ }^{-1} \mathrm{NH}_{4}^{+}, 4686 \mu \mathrm{mol} \mathrm{L}{ }^{-1} \mathrm{~K}^{+}$and $930 \mu \mathrm{mol} \mathrm{L}{ }^{-1} \mathrm{PO}_{4}{ }^{-}$) instead of deionised water. Nutrients in the high nutrient treatments had been largely depleted to comparable levels as in the low nutrient treatments at harvest (Fig. S3). Pots were placed in pairs per species, own and mix soil, in a randomised block design in the greenhouse and grown for 6 weeks under comparable conditions as in the conditioning phase. Leaf counts indicated that initial positive soil history effects occurring for some species in the first 2 weeks faded or turned negative over time consistent with Dudenhöffer et al. (2018) (data not shown). This indicates that the time period of our feedback phase was long enough to observe an accumulation of biotic soil effects. After 6 weeks, shoots including flowers were cut off at the base, dried at $70{ }^{\circ} \mathrm{C}$ for at least $72 \mathrm{~h}$ and weighed. Roots were washed out of the soil on a sieve with tap water during which obvious dead roots from the previous phase were discarded. Approximately $20 \mathrm{mg}$ (fresh weight) of these cleaned roots were stored in $70 \%$ ethanol to determine mycorrhizal colonisation. The remainder was dried at $70{ }^{\circ} \mathrm{C}$ for at least $72 \mathrm{~h}$ and weighed.

Mycorrhizal fungi staining and counting

Roots stored in $70 \%$ ethanol were cleared in $10 \% \mathrm{KOH}$ $(w / v)$ for $1 \mathrm{~d}$, after which the solution was refreshed and roots were stored for another 1-2 d, until roots were sufficiently cleared (duration was species dependent). After this, roots were rinsed with $85 \%$ ethanol until no pigment leached out anymore. Roots were then placed in $5 \% \mathrm{HCl}$ for $5 \mathrm{~min}$ at room temperature. Mycorrhizal 
fungi were stained by placing roots in a $0.05 \%$ trypan blue solution $(10 \mathrm{~mL}$ glacial acetic acid, $200 \mathrm{~mL}$ glycer-

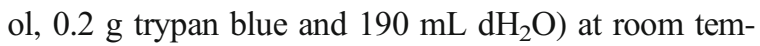
perature for $1-2 \mathrm{~h}$ (duration was species dependent). Roots were stored in acid glycerol overnight and stored in fresh acid glycerol until counting. Approximately ten, randomly selected, cleared and stained root pieces of approximately $1 \mathrm{~cm}$ were randomly placed on a microscopic slide with a $0.1 \mathrm{~mm}$ grid. Horizontal grid lines were traced under a light microscope and on the first 100 grid intersects with a root fragment, mycorrhizal structures (hyphae, vesicles and spores; arbuscules were not observed) were noted according to McGonigle et al. (1990). Relative mycorrhizal colonisation was calculated by dividing the number of incidences that a mycorrhizal structure was observed by the number of incidences that no mycorrhizal structure was observed $(n=3)$.

Calculations and statistics

Plant-soil feedback was calculated on the average biomass of the four individuals in a pot and for each pair of own and mix treated soils as (dry weight own soil $_{-}$dry weight $_{\text {mix soil }}$ / dry weight $t_{\text {mix soil }}$, both based on either shoot or root dry weight $(n=6)$. We analysed all data using ANOVA with generalised least square (gls) models from the nlme package (Pinheiro et al. 2017) in R 3.4.3 ( $\mathrm{R}$ Core Team 2017). Model validation followed recommendations of Zuur et al. (2010). Full models included 'species', 'nutrient' and, in case of biomasses and soil nutrients, 'soil history', and their interactions as fixed factors. Additionally, models testing the effect of mycorrhizal spore addition included the fixed factor 'mycorrhizae addition' with all its interactions.

Inclusion of the factor 'species' often resulted in heterogeneity of variances. In these cases, models were run with a variance structure allowing for differences in variance between species according to Zuur et al. (2009), using varIdent from the nlme package (Pinheiro et al. 2017). Full models including 'mycorrhizae addition' often showed heterogeneity of variances because of the factor 'nutrient' and, in some cases, 'mycorrhizae addition', and were therefore run with a weighted variance structure of one or two of these factors (Zuur et al. 2009). Full models for Leontodon and Plantago including 'mycorrhizae addition' and also 'soil history' as fixed factor were run per species, because heterogeneity of variances could not be overcome due to low statistical power. Data on $\mathrm{NO}_{3}{ }^{-}$in the feedback phase was ln-transformed to meet assumptions of a normal distribution of the model residuals. After the full models were defined, post-hoc tests were run on these models using the emmeans-package (Lenth 2018).

\section{Results}

Nutrient addition eliminated plant-soil feedback

Plant-soil feedback of two grasses, Anthoxanthum and Festuca, and two forbs, Leontodon and Plantago, was determined on soil with low and high nutrient availability. Nutrient addition resulted in higher aboveground biomass of every species in each soil, whereas belowground biomass was not always affected by nutrient addition (Fig. S4). For plant-soil feedback based on shoot biomass, no overall effect of plant species or nutrient addition occurred. However, a significant interaction between plant species and nutrient addition was observed (Table 1). Plant-soil feedback based on shoot biomass of the two grasses Anthoxanthum and Festuca was absent and not significantly affected by nutrient addition (Fig. 2a). Leontodon and Plantago, on the other hand, showed positive and negative shoot feedback on low nutrient soil, respectively. Addition of nutrients largely eliminated this feedback (Fig. 2a).

For plant-soil feedback based on root biomass, no overall significant effect of nutrient addition occurred (Table 2). Plant-soil feedback based on root biomass was negative for Anthoxanthum and neutral for Festuca and Plantago independently of the nutrient addition treatment (Fig. 2b). Leontodon, on the other hand, showed neutral feedback on low nutrient soil, which turned negative with addition of nutrients (Fig. 2b).

Table 1 ANOVA results of species, nutrient addition and their interaction on plant-soil feedback based on shoot and root biomass

\begin{tabular}{|c|c|c|c|c|c|}
\hline & \multirow[b]{3}{*}{$\mathrm{df}$} & \multicolumn{4}{|c|}{ Plant-soil feedback } \\
\hline & & \multicolumn{2}{|l|}{ Shoot } & \multicolumn{2}{|l|}{ Root } \\
\hline & & $\chi^{2}$ & $p$ & $\chi^{2}$ & $p$ \\
\hline Species & 3 & 4.222 & 0.239 & 5.358 & 0.147 \\
\hline Nutrient & 1 & 0.122 & 0.727 & 0.083 & 0.774 \\
\hline Species $\mathrm{x}$ nutrient & 3 & 32.388 & $<0.001$ & 4.882 & 0.181 \\
\hline
\end{tabular}

Significant effects $(p<0.05)$ presented in bold 

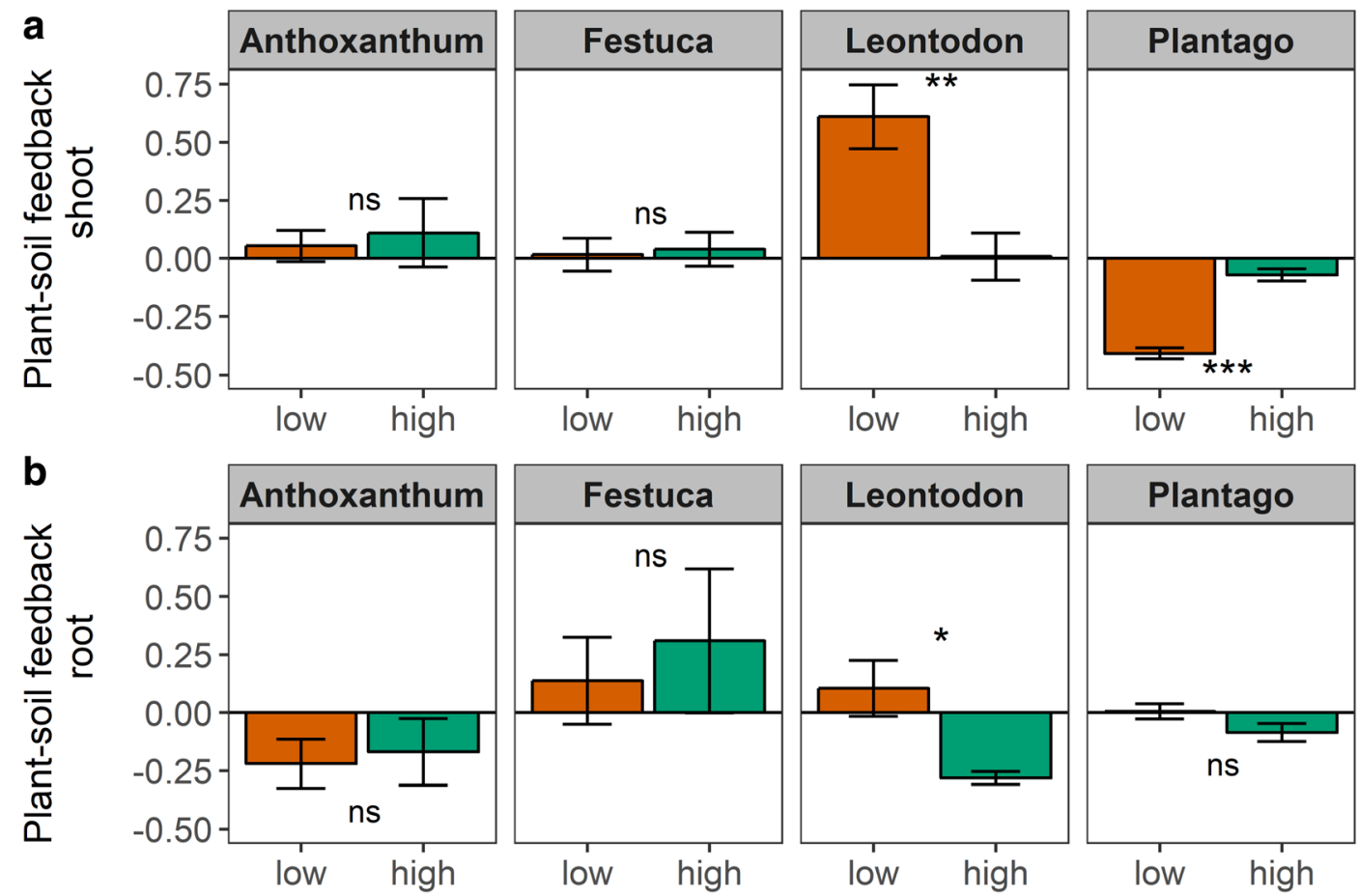

Fig. 2 Plant-soil feedback based on (a) shoot and (b) root biomass of Anthoxanthum, Festuca, Leontodon and Plantago on low (orange) and high (green) nutrient soil. Plant-soil feedback was calculated as the percentage increase/decrease in biomass on own conditioned soil compared to a mix of conditioned soils of all four

Mycorrhizal fungi addition increased positive and decreased negative feedback

Plant-soil feedback of Leontodon and Plantago was, in addition to nutrient addition, also determined with addition of mycorrhizal spores at the seedlings. Relative colonisation of Leontodon roots by mycorrhizae was only significantly affected by nutrient status of the soil and not by mycorrhizal spore addition and soil history species $(n=4-6)$. Positive values indicate species that grew better on own than on mix soil and negative values indicate species that grew worse on own than on mix soil. Significance codes: $* * *=p<0.001, * *=p<0.01, *=p<0.05, \mathrm{~ns}=p>$ 0.05

(Table S1; Fig. S5). Leontodon roots had a higher relative colonisation in high nutrient soils than in low nutrients soils (Fig. S5). Relative mycorrhizal fungi colonisation of Plantago roots, on the other hand, was significantly affected by both soil history and mycorrhizal spore addition (Table S1). On low nutrient soils, relative colonisation did not significantly differ between soil history and mycorrhizae treatments. On high nutrient soils, however, relative colonisation was higher with

Table 2 ANOVA results of nutrient and mycorrhizae (AMF) addition and their interaction on plant-soil feedback based on shoot and root biomass of Leontodon and Plantago

\begin{tabular}{|c|c|c|c|c|c|c|c|c|c|}
\hline & \multirow[b]{3}{*}{$\mathrm{df}$} & \multicolumn{4}{|c|}{ Plant-soil feedback - Leontodon } & \multicolumn{4}{|c|}{ Plant-soil feedback - Plantago } \\
\hline & & \multicolumn{2}{|l|}{ Shoot } & \multicolumn{2}{|l|}{ Root } & \multicolumn{2}{|l|}{ Shoot } & \multicolumn{2}{|l|}{ Root } \\
\hline & & $\chi^{2}$ & $p$ & $\chi^{2}$ & $p$ & $\chi^{2}$ & $p$ & $\chi^{2}$ & $p$ \\
\hline nutrient & 1 & 11.358 & $<0.001$ & 9.737 & 0.002 & 92.131 & $<0.001$ & 0.682 & 0.409 \\
\hline AMF & 1 & 0.836 & 0.361 & 10.544 & 0.001 & 0.587 & 0.587 & 1.188 & 0.276 \\
\hline nutrient $x$ AMF & 1 & 0.792 & 0.373 & 1.686 & 0.194 & 8.207 & 0.004 & 3.504 & 0.061 \\
\hline
\end{tabular}

Significant effects $(p<0.05)$ presented in bold 
addition of mycorrhizal spores on both own and mix conditioned soil (Fig. S5).

Above- and belowground biomass of Leontodon and Plantago were only slightly affected by mycorrhizal spore addition (Fig. S6). Despite this and the small effects of mycorrhizal spore addition on visible mycorrhizal root colonisation, mycorrhizal spore addition did have significant effects on plant-soil feedback of the root system of Leontodon and interacted significantly with nutrient availability for plant-soil feedback based on the shoot of Plantago (Table 2; Fig. 3). Leontodon plant-soil feedback based on root biomass was positively affected by mycorrhizal spore addition and became significantly more positive on low nutrient soil, and the negative plant-soil feedback on high nutrient soil was significantly neutralised (Table 2; Fig. 3b). Plant-soil feedback based on shoot biomass of Leontodon, on the other hand, was not significantly affected by mycorrhizal spore addition (Table 2; Fig. 3a).
For Plantago plant-soil feedback based on shoot biomass became significantly less negative with mycorrhizal spore addition on low nutrient soil, whereas the neutral feedback on high nutrient soil was not affected by mycorrhizae addition (Fig. 3a). Plant-soil feedback based on root biomass of Plantago was not significantly affected by mycorrhizal spore addition on both low and high nutrient soil (Table 2; Fig. 3b).

\section{Discussion}

Plant-soil feedback and nutrient availability

We found that plant-soil feedback based on shoot biomass, whether positive or negative, was eliminated with addition of nutrients. Species with neutral plant-soil feedback were not affected by nutrient addition. This is consistent with the general change in plant-soil feedback with nutrient addition that Petermann et al. (2008)
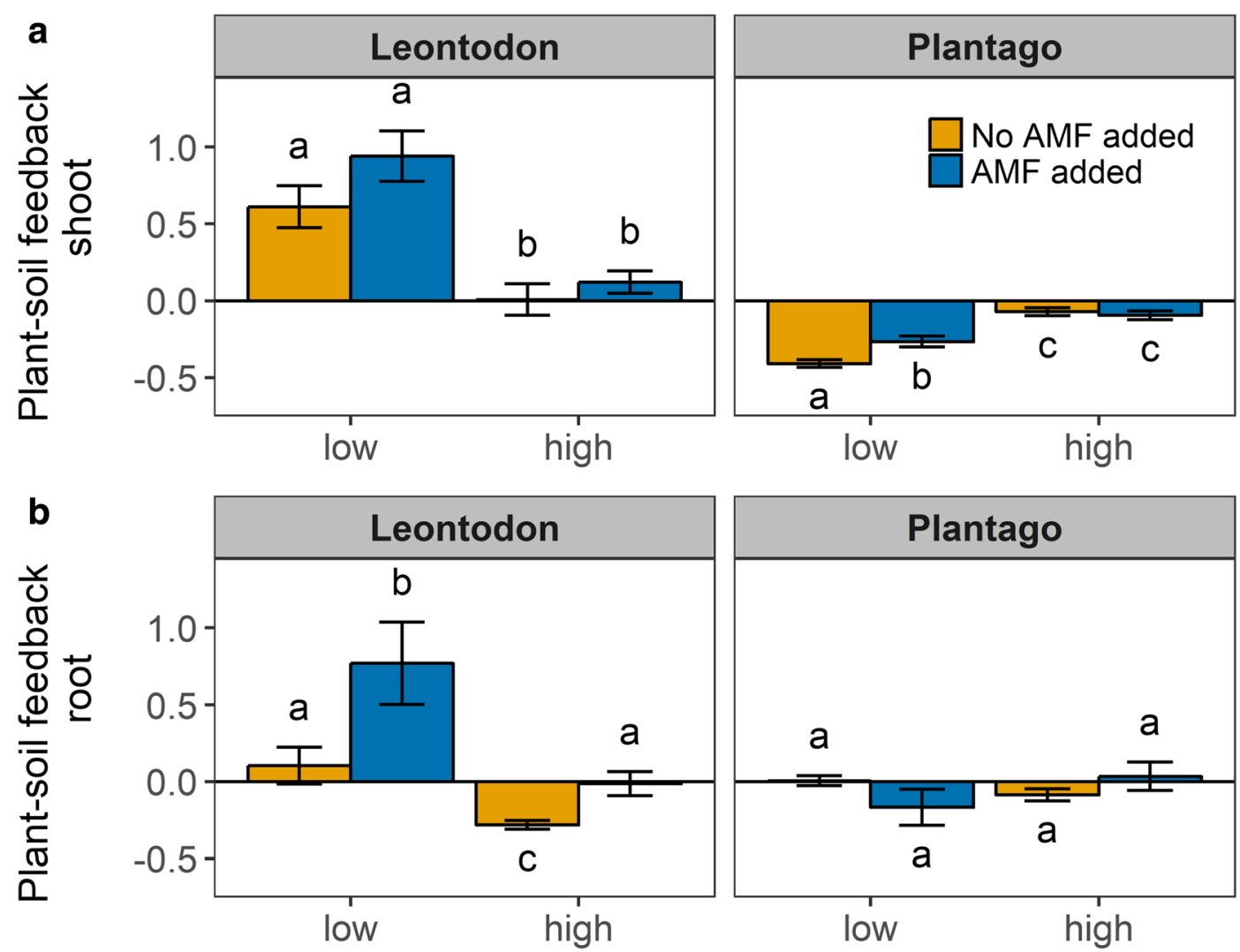

Fig. 3 Plant-soil feedback based on (a) shoot and (b) root biomass of Leontodon and Plantago in low and high nutrient conditions, and with (blue) and without (yellow) addition of mycorrhizae spores (AMF) at seedling planting $(n=4-6)$. Different letters

indicate significant differences $(p<0.05)$. Plant-soil feedback values without mycorrhizae spore addition are the same as in Fig. 2 
observed throughout 24 grassland species and the hypothesis of van der Heijden et al. (2008) that significance of microbial communities is highest at low nutrient availability. Our experimental approach, which quantifies the degree of microbial host specialisation (own versus a mixture of conditioned soil) (Lekberg et al. 2018), suggests that host specialisation was lost with nutrient addition. The neutralisation of the negative plant-soil feedback found for Plantago suggests that even though pathogens are often found to thrive in high nutrient soils (Paungfoo-Lonhienne et al. 2015; Whitaker et al. 2015; Wei et al. 2018; Veach et al. 2018), expected negative effects on plant growth (Rúa and Umbanhowar 2015; Revillini et al. 2016; van der Putten et al. 2016; Lekberg et al. 2018) were overcome. This possibly occurred due to increased overall fitness of the plant due to release from nutrient stress, and, consequently, an increase in tolerance to speciesspecific soil-borne pathogens. Simultaneously, competition between plants and soil micro-organisms may be less strong due to high nutrient availability (Schimel and Bennett 2004; Liu et al. 2016; in 't Zandt et al. 2018), further decreasing negative plant-soil feedback effects.

For Leontodon, plant-soil feedback based on shoot biomass was positive under low nutrient conditions. Its elimination with nutrient addition may have occurred due to loss of mutualistic associations, i.e., positive associations were less frequently established or were unable to increase plant biomass any further than already occurred due to increased nutrient availability. Such decreased mutualistic associations with increasing nutrient availability have been shown to occur for mycorrhizal (Egerton-Warburton and Allen 2000; Corkidi et al. 2002; Treseder and Allen 2002; Treseder 2004; Avolio et al. 2014; Leff et al. 2015), Rhizobium (Vargas et al. 2000; Valladares et al. 2002) and plant growthpromoting rhizobacteria mutualisms (Shaharoona et al. 2008; Adesemoye et al. 2009).

Our results also show that nutrient availability effects of plant-soil feedback based on root system biomass do not match those of shoot biomass. In high nutrient soil, Leontodon showed an unexpected negative plant-soil feedback based on root biomass compared to no plantsoil feedback on low nutrient soil. A loss in significance of mutualistic associations together with a potentially flourishing pathogenic community (PaungfooLonhienne et al. 2015; Whitaker et al. 2015; Wei et al. 2018; Veach et al. 2018) may have resulted in patho- genic effects to prevail, and thus a negative plant-soil feedback on high nutrient soil. These negative effects were, however, not strong enough to show in the aboveground biomass, but may indicate that positive plant-soil feedback species experience small negative effects on own, conditioned soil with nutrient increase. Future research needs to establish whether this holds for positive feedback species in general and how this relation changes along a nutrient gradient.

Plant-soil feedback, mycorrhizal fungi interactions and nutrient availability

Mycorrhizal spore addition to the seedlings generally decreased negative and increased positive plant-soil feedback. This is consistent with the positive relation between plant-soil feedback and root mycorrhizal fungi colonisation on own conditioned soil that Cortois et al. (2016) found across 48 grassland species, and other studies experimentally stimulating mycorrhizal colonisation (Anacker et al. 2014; García-Parisi and Omacini 2017). Our results show that these positive mycorrhizae effects interacted with soil nutrient availability. Negative feedback based on shoot biomass of Plantago lessened with mycorrhizal spore addition, but only on low nutrient soil. Also the increase in positive feedback of Leontodon with mycorrhizal spore addition only occurred on low nutrient soil. This is consistent with the notion that positive associations may become superfluous in high nutrient soil. Yet, for Leontodon, mycorrhizal fungi inoculation on high nutrient soil did affect plant-soil feedback based on root system biomass, and negative feedback became neutral. This together with the expectation that nutrient uptake was hardly limiting on high nutrient soil, suggests that the positive effect of mycorrhizal spore addition may result from protection against species-specific pathogens occurring on own soil (Sikes 2010), rather than an increased nutrient uptake via mycorrhizal networks.

Mycorrhizal fungi addition did not necessarily increase visible root colonisation, despite observed positive effects on plant-soil feedback. This is likely because root colonisation of mycorrhizal fungi is not the sole determinant of the functionality of the mutualistic interaction. Instead of the expected increase in mycorrhizal root colonisation, mycorrhizal spore addition may have resulted in more soil hyphae, 
higher nutrient mobilisation capacity of the fungus and/or more nutrient exchange structures (Munkvold et al. 2004; Smith et al. 2004; Jansa et al. 2005; Feddermann et al. 2010). This may arise from an earlier developing plant-mycorrhizae association and result in the observed positive plant-soil feedback effects. Early effects of mycorrhizal fungi on plant-soil feedback direction and strength thus likely encompasses a much larger and complex pathway that is not captured in root colonisation determinants.

Soil nutrient increase and species co-existence theory

Microbial mediated plant-soil feedback is considered to play critical roles in plant community assembly via strong, negative effects on abundant species, resulting in reduced growth and subsequent local replacement (e.g. Bever et al. 2012). Such hypothesized continuous, small-scale species replacements may be affected by soil nutrient availability increase. If the neutralisation of plant-soil feedback with nutrient addition we observed occurs for all species in a diverse community, then continuous, small-scale species replacements may no longer take place in high nutrient environments. In this case, the best competitor will win and mono-dominate the system. Consequentially, high plant diversity can only be maintained in low nutrient environments, and will be lost with nutrient increase due to loss of microbial mediated plant-soil feedback. This is in line with observed loss of plant, bacterial and fungal diversity in the soil when soil nutrient availability increased (e.g., Clark and Tilman 2008; Smith et al. 2008; Coolon et al. 2013; Tedersoo et al. 2014). Future work should test whether root microbial communities between plant species in low nutrient soil are more distinct than in high nutrient soil, whether nutrient addition results in mono-dominance of strong competitor plant species, and whether this is linked to a loss of negative plant-soil feedback.

Acknowledgements We are grateful to Hannie de Caluwe, Thom van den Brink, Peter Cruijsen, Annemiek Smit-Tiekstra, Carmen Vazquez Martin, Stan Prinsen, the greenhouse staff Gerard van der Weerden, Harry van Zuijlen, Walter Hendrickx and Yvette Evers for practical assistance, and Sebastian Krosse for chemical analysis. This research was supported by the Netherlands Organisation for Scientific Research (NWO grant 824.01.003).

Data availability The data used in these analyses are archived in the DANS-EASY data repository: https://doi.org/10.17026/dans-xas-6hts
Open Access This article is distributed under the terms of the Creative Commons Attribution 4.0 International License (http:// creativecommons.org/licenses/by/4.0/), which permits unrestricted use, distribution, and reproduction in any medium, provided you give appropriate credit to the original author(s) and the source, provide a link to the Creative Commons license, and indicate if changes were made.

\section{References}

Adesemoye AO, Torbert HA, Kloepper JW (2009) Plant growth-promoting rhizobacteria allow reduced application rates of chemical fertilizers. Microb Ecol 58:921929. https://doi.org/10.1007/s00248-009-9531-y

Anacker BL, Klironomos JN, Maherali H, Reinhart KO, Strauss SY (2014) Phylogenetic conservatism in plant-soil feedback and its implications for plant abundance. Ecol Lett 17:16131621. https://doi.org/10.1111/ele.12378

Avolio ML, Koerner SE, La Pierre KJ, Wilcox KR, Wilson GWT, Smith MD, Collins SL (2014) Changes in plant community composition, not diversity, during a decade of nitrogen and phosphorus additions drive above-ground productivity in a tallgrass prairie. J Ecol 102:1649-1660. https://doi.org/10.1111/1365-2745.12312

Bates ST, Berg-Lyons D, Caporaso JG, Walters WA, Knight R, Fierer N (2011) Examining the global distribution of dominant archaeal populations in soil. ISME J 5:908-917. https://doi.org/10.1038/ismej.2010.171

Bever JD, Westover KM, Antonovics J (1997) Incorporating the soil community into plant population dynamics: the utility of the feedback approach. J Ecol 85:561-573. https://doi.org/10.2307/2960528

Bever JD, Platt TG, Morton ER (2012) Microbial population and community dynamics on plant roots and their feedbacks on plant communities. Annu Rev Microbiol 66:265-283. https://doi.org/10.1146/annurev-micro-092611-150107

Bever JD, Mangan SA, Alexander HM (2015) Maintenance of plant species diversity by pathogens. Annu Rev Ecol Evol Syst 46:305-325. https://doi.org/10.1146/annurev-ecolsys112414-054306

Clark CM, Tilman D (2008) Loss of plant species after chronic low-level nitrogen deposition to prairie grasslands. Nature 451:712-715. https://doi.org/10.1038/nature06503

Coolon JD, Jones KL, Todd TC, Blair JM, Herman MA (2013) Long-term nitrogen amendment alters the diversity and assemblage of soil bacterial communities in tallgrass prairie. PLoS One 8:1-11. https://doi.org/10.1371 /journal.pone.0067884

Corkidi L, Rowland DL, Johnson NC, Allen EB (2002) Nitrogen fertilization alters the functioning of arbuscular mycorrhizae at two semiarid grasslands. Plant Soil 240:299-310. https://doi.org/10.1023/A:1015792204633

Cortois R, Schröder-Georgi T, Weigelt A, van der Putten WH, De Deyn GB (2016) Plant-soil feedbacks: role of plant functional group and plant traits. J Ecol 104:1608-1617. https://doi. org/10.1111/1365-2745.12643 
Dudenhöffer J-H, Ebeling A, Klein A-M, Wagg C (2018) Beyond biomass: soil feedbacks are transient over plant life stages and alter fitness. J Ecol 106:230-241. https://doi.org/10.1111 /1365-2745.12870

Egerton-Warburton LM, Allen EB (2000) Shifts in arbuscular mycorrhizal communities along an anthropogenic nitrogen deposition gradient. Ecol Appl 10:484-496. https://doi.org/ 10.1890/1051-0761(2000)010[0484:SIAMCA]2.0.CO;2

Ehrenfeld JG, Ravit B, Elgersma K (2005) Feedback in the plantsoil system. Annu Rev Environ Resour 30:75-115. https://doi.org/10.1146/annurev.energy.30.050504.144212

Erktan A, McCormack ML, Roumet C (2018) Frontiers in root ecology: recent advances and future challenges. Plant Soil 424:1-9. https://doi.org/10.1007/s11104-018-3618-5

Feddermann N, Finlay R, Boller T, Elfstrand M (2010) Functional diversity in arbuscular mycorrhiza - the role of gene expression, phosphorous nutrition and symbiotic efficiency. Fungal Ecol 3:1-8. https://doi.org/10.1016/j.funeco.2009.07.003

Fierer N, Strickland MS, Liptzin D, Bradford MA, Cleveland CC (2009) Global patterns in belowground communities. Ecol Lett 12:1238-1249. https://doi.org/10.1111/j.14610248.2009.01360.x

García-Parisi PA, Omacini M (2017) Arbuscular mycorrhizal fungi can shift plant-soil feedback of grass-endophyte symbiosis from negative to positive. Plant Soil 419:1323. https://doi.org/10.1007/s11104-017-3216-y

Harrison KA, Bardgett RD (2010) Influence of plant species and soil conditions on plant-soil feedback in mixed grassland communities. J Ecol 98:384-395. https://doi.org/10.1111 j.1365-2745.2009.01614.x

in 't Zandt D, Fritz C, Wichern F (2018) In the land of plenty: catch crops trigger nitrogen uptake by soil microorganisms. Plant Soil 423:549-562. https://doi.org/10.1007/s11104-0173540-2

Jansa J, Mozafar A, Frossard E (2005) Phosphorus acquisition strategies within arbuscular mycorrhizal fungal community of a single field site. Plant Soil 276:163176. https://doi.org/10.1007/s11104-005-4274-0

Ke PJ, Miki T (2015) Incorporating the soil environment and microbial community into plant competition theory. Front Microbiol 6:1-16. https://doi.org/10.3389/fmicb.2015.01066

Klironomos JN (2002) Feedback with soil biota contributes to plant rarity and invasiveness in communities. Nature 417: 67-70. https://doi.org/10.1038/417067a

Laliberté E, Kardol P, Didham RK, Teste FP, Turner BL, Wardle DA (2017) Soil fertility shapes belowground food webs across a regional climate gradient. Ecol Lett 20:1273-1284. https://doi.org/10.1111/ele.12823

Leff JW, Jones SE, Prober SM, Barberán A, Borer ET, Firn JL, Harpole WS, Hobbie SE, Hofmockel KS, Knops JMH, McCulley RL, La Pierre K, Risch AC, Seabloom EW, Schütz M, Steenbock C, Stevens CJ, Fierer N (2015) Consistent responses of soil microbial communities to elevated nutrient inputs in grasslands across the globe. Proc Natl Acad Sci 112:10967-10972. https://doi.org/10.1073 /pnas. 1508382112

Lekberg Y, Waller LP (2016) What drives differences in arbuscular mycorrhizal fungal communities among plant species? Fungal Ecol 24:135-138. https://doi.org/10.1016/j. funeco.2016.05.012
Lekberg Y, Bever JD, Bunn RA, Callaway RM, Hart MM, Kivlin SN, Klironomos J, Larkin BG, Maron JL, Reinhart KO, Remke M, van der Putten WH (2018) Relative importance of competition and plant-soil feedback, their synergy, context dependency and implications for coexistence. Ecol Lett 21: 1-14. https://doi.org/10.1111/ele.13093

Lenth R (2018) emmeans: Estimated marginal means, aka leastsquares means. https://cran.r-project.org/package=emmeans

Liu Q, Qiao N, Xu X, Xin X, Han JY, Tian Y, Ouyang H, Kuzyakov Y (2016) Nitrogen acquisition by plants and microorganisms in a temperate grassland. Sci Rep 6:22642. https://doi.org/10.1038/srep22642

Luo S, De Deyn GB, Jiang B, Yu S (2017) Soil biota suppress positive plant diversity effects on productivity at high but not low soil fertility. J Ecol 105:17661774. https://doi.org/10.1111/1365-2745.12773

Manning P, Morrison SA, Bonkowski M, Bardgett RD (2008) Nitrogen enrichment modifies plant community structure via changes to plant-soil feedback. Oecologia 157:661-673. https://doi.org/10.1007/s00442-008-1104-0

McGonigle TP, Miller MH, Evans DG, Fairchild GL, Swan JA (1990) A new method which gives an objective measure of colonization of roots by vesicular-arbuscular mycorrhizal fungi. New Phytol 115:495-501. https://doi.org/10.1111 j.1469-8137.1990.tb00476.x

Mitchell RJ, Campbell CD, Chapman SJ, Cameron CM (2010) The ecological engineering impact of a single tree species on the soil microbial community. J Ecol 98:50-61. https://doi.org/10.1111/j.1365-2745.2009.01601.x

Munkvold L, Kjøller R, Vestberg M, Rosendahl S, Jakobsen I (2004) High functional diversity within species of arbuscular mycorrhizal fungi. New Phytol 164:357364. https://doi.org/10.1111/j.1469-8137.2004.01169.x

Olsen S, Cole C, Watanabe F, Dean L (1954) Estimation of available phosphorus in soils by extraction with sodium bicarbonate. In: USDA Circular Nr 939. US Gov. Print. Office, Washington, DC, USA

Paungfoo-Lonhienne C, Yeoh YK, Kasinadhuni NRP, Lonhienne TGA, Robinson N, Hugenholtz P, Ragan MA, Schmidt S (2015) Nitrogen fertilizer dose alters fungal communities in sugarcane soil and rhizosphere. Sci Rep 5:1-6. https://doi.org/10.1038/srep08678

Petermann JS, Fergus AJF, Turnbull LA, Schmid B (2008) JanzenConnell effects are widespread and strong enough to maintain diversity in grasslands. Ecology 89:2399-2406. https://doi.org/10.1890/07-2056.1

Pinheiro J, Bates D, DebRoy S, Sarkar D, Team RC (2017) nlme: linear and nonlinear mixed effects models. https://cran.r-project.org/package=nlme

R Core Team (2017) R: a language and environment for statistical computing. https://www.r-project.org/

Ramirez KS, Lauber CL, Knight R, Bradford MA, Fierer N (2010) Consistent effects of nitrogen fertilization on soil bacterial communities in contrasting systems. Ecology 91:3463-3470. https://doi.org/10.1890/10-0426.1

Ramirez KS, Craine JM, Fierer N (2012) Consistent effects of nitrogen amendments on soil microbial communities and processes across biomes. Glob Chang Biol 18:1918-1927. https://doi.org/10.1111/j.1365-2486.2012.02639.x

Revillini D, Gehring CA, Johnson NC (2016) The role of locally adapted mycorrhizas and rhizobacteria in plant-soil feedback 
systems. Funct Ecol 30:1086-1098. https://doi.org/10.1111 /1365-2435.12668

Rúa MA, Umbanhowar J (2015) Resource availability determines stability for mutualist-pathogen-host interactions. Theor Ecol 8:133-148. https://doi.org/10.1007/s12080-014-0237-5

Schimel JP, Bennett J (2004) Nitrogen mineralization: challenges of a changing paradigm. Ecology 85:591-602. https://doi.org/10.1890/03-8002

Shaharoona B, Naveed M, Arshad M, Zahir ZA (2008) Fertilizerdependent efficiency of pseudomonads for improving growth, yield, and nutrient use efficiency of wheat (Triticum aestivum L.). Appl Microbiol Biotechnol 79:147155. https://doi.org/10.1007/s00253-008-1419-0

Sikes BA (2010) When do arbuscular mycorrhizal fungi protect plant roots from pathogens? Plant Signal Behav 5:763-765. https://doi.org/10.4161/psb.5.6.11776

Smith SE, Smith FA, Jakobsen I (2004) Functional diversity in arbuscular mycorrhizal (AM) symbioses: the contribution of the mycorrhizal P uptake pathway is not correlated with mycorrhizal responses in growth or total $\mathrm{P}$ uptake. New Phytol 162:511-524. https://doi.org/10.1111/j.14698137.2004.01039.x

Smith RS, Shiel RS, Bardgett RD, Millward D, Corkhill P, Evans P, Quirk H, Hobbs PJ, Kometa ST (2008) Long-term change in vegetation and soil microbial communities during the phased restoration of traditional meadow grassland. J Appl Ecol 45:670-679. https://doi.org/10.1111/j.13652664.2007.01425.x

Tedersoo L, Bahram M, Polme S, Koljalg U, Yorou NS, Wijesundera R, Ruiz LV, Vasco-Palacios AM, Thu PQ, Suija A, Smith ME, Abarenkov K et al (2014) Global diversity and geography of soil fungi. Science 346:12566881256688. https://doi.org/10.1126/science. 1256688

Treseder KK (2004) A meta-analysis of mycorrhizal responses to nitrogen, phosphorus, and atmospheric $\mathrm{CO} 2$ in field studies. New Phytol 164:347-355. https://doi.org/10.1111/j.14698137.2004.01159.x

Treseder KK (2008) Nitrogen additions and microbial biomass: a meta-analysis of ecosystem studies. Ecol Lett 11:1111-1120. https://doi.org/10.1111/j.1461-0248.2008.01230.x

Treseder KK, Allen MF (2002) Direct nitrogen and phosphorus limitation of arbuscular mycorrhizal fungi: a model and field test. New Phytol 155:507-515. https://doi.org/10.1046 /j.1469-8137.2002.00470.x

Valladares F, Villar-Salvador P, Domínguez S, Fernández-Pascual M, Peñuelas JL, Pugnaire FI (2002) Enhancing the early performance of the leguminous shrub Retama sphaerocarpa
(L.) Boiss.: fertilisation versus rhizobium inoculation. Plant Soil 240:253-262. https://doi.org/10.1023/A:1015752320773

van der Heijden MGA, Bardgett RD, van Straalen NM (2008) The unseen majority: soil microbes as drivers of plant diversity and productivity in terrestrial ecosystems. Ecol Lett 11:296310. https://doi.org/10.1111/j.1461-0248.2007.01139.x

van der Putten WH, Bardgett RD, Bever JD, Bezemer TM, Casper BB, Fukami T, Kardol P, Klironomos JN, Kulmatiski A, Schweitzer JA, Suding KN, Van de Voorde TFJ, Wardle DA (2013) Plant-soil feedbacks: the past, the present and future challenges. J Ecol 101:265-276. https://doi. org/10.1111/1365-2745.12054

van der Putten WH, Bradford MA, Pernilla Brinkman E, van de Voorde TFJ, Veen GF (2016) Where, when and how plantsoil feedback matters in a changing world. Funct Ecol 30: 1109-1121. https://doi.org/10.1111/1365-2435.12657

Vargas MAT, Mendes IC, Hungria M (2000) Response of fieldgrown bean (Phaseolus vulgaris L.) to rhizobium inoculation and nitrogen fertilization in two Cerrados soils. Biol Fertil Soils 32:228-233. https://doi.org/10.1007/s003740000240

Veach AM, Stokes CE, Knoepp J, Jumpponen A, Baird R (2018) Fungal communities and functional guilds shift along an elevational gradient in the southern Appalachian Mountains. Microb Ecol 76:156-168. https://doi. org/10.1007/s00248-017-1116-6

Wei W, Yang M, Liu Y, Huang H, Ye C, Zheng J, Guo C, Hao M, He X, Zhu S (2018) Fertilizer N application rate impacts plant-soil feedback in a sanqi production system. Sci Total Environ 633:796-807. https://doi.org/10.1016/j. scitotenv.2018.03.219

Whitaker BK, Rúa MA, Mitchell CE (2015) Viral pathogen production in a wild grass host driven by host growth and soil nitrogen. New Phytol 207:760-768. https://doi.org/10.1111 /nph.13369

Zuur AF, Ieno EN, Walker NJ, Saveliev AA, Smith GM (2009) Mixed effects models and extensions in ecology with R. Springer-Verlag, New York

Zuur AF, Ieno EN, Elphick CS (2010) A protocol for data exploration to avoid common statistical problems. Methods Ecol Evol 1:3-14. https://doi.org/10.1111 /j.2041-210X.2009.00001.x

Publisher's note Springer Nature remains neutral with regard to jurisdictional claims in published maps and institutional affiliations. 